\title{
Suitability of Cow Horn as Filler in an Epoxy Composite
}

\author{
${ }^{1}$ AMBALI, IO; ${ }^{1}$ SHUAIB-BABATA, YL; ${ }^{1}$ ALASI, TO; ${ }^{1}$ AREMU, IN; ${ }^{2}$ IBRAHIM, HK; \\ ${ }^{4}$ ELAKHAME, ZU; ${ }^{3}$ ABDULRAMAN, SO \\ ${ }^{1}$ Department of Materials and Metallurgical Engineering, ${ }^{2}$ Department of Mechanical Engineering, University of Ilorin, Ilorin, Nigeria . \\ ${ }^{3}$ Department of Material Science and Engineering, Kwara State University, Malete.Nigeria \\ ${ }^{4}$ Dept of Project Design and Development, Federal Institute of Industrial Research, Oshodi, Lagos, Nigeria \\ *Corresponding Author Email: sylbabata@unilorin.edu.ng
}

\begin{abstract}
This study focuses on assessment of cow horn as filler in an epoxy composite. A particle-reinforced composite was developed using horn particles (HP) and epoxy resin with filler of varying percentage weight (5\%, $10 \%, 15 \%, 20 \% .25 \%, 30 \%, 35 \%, 40 \%$ ) at particle sizes of 100 and $150 \mu \mathrm{m}$. The composites were developed by hand lay-up technique with varying process parameters. The properties of the developed composites were examined through tensile, flexural and impact tests. The results showed that the tensile properties of the polymers reduced with the incorporation of the cow horn as filler. But at higher curing temperature, a better strength was achieved. Meanwhile, the flexural and impact properties of the polymers increased with the incorporation of the fiber in no particular order. The composite materials with particle size of $100 \mu \mathrm{m}$ with curing temperature of $80^{\circ} \mathrm{C}$ exhibited higher tensile $(37.58$ $\mathrm{MPa}$ ) and impact properties (74 J) than the lower particles. Generally, the cow horn was found to be a good potential filler in the composite if prepared using higher curing temperature as exhibited through its mechanical properties.
\end{abstract}

\section{DOI: https://dx.doi.org/10.4314/jasem.v23i3.17}

Copyright: Copyright (C) 2019 Ambali et al. This is an open access article distributed under the Creative Commons Attribution License (CCL), which permits unrestricted use, distribution, and reproduction in any medium, provided the original work is properly cited.

Dates: Received: 17 November 2018; Revised: 19 January 2019; Accepted 22 January 2019

Keywords: Composite materials, Cow horn, Epoxy resin, Filler and Strength

Failure of materials in service and its consequences have been major concerns amongst Engineers leading to emergent of modern materials for different engineering applications. Modern engineering materials include metals, polymers, ceramics and composites. Ceramics, although are strong in compression, but generally weak in tension. Meanwhile, metals tend to have equal strengths both in tension and compression; composites have been developed to overcome the deficiencies of members of a particular class of materials (John, 1992). With extensive applications of polymers and its composites, due to their excellent mechanical properties, the demands for the materials are increasing (Fang et al., 2017). There are different composites that have been considered over time in lieu with optimizing materials to achieve good mechanical properties. Natural fibers are being considered as an alternative reinforcement in polymer composite due to their advantages over conventional glass and carbon (Saheb and Jog, 1999). These advantages include low cost, comparable specific tensile properties, renewability, recyclability, biodegradability, less health risk, non-irritation to skin, and non-abrasive to the equipment (Malkapuram et al., 2009). Generally, polymers are classified as thermoplastics and thermosetting. Thermoplastic materials currently dominate as matrices for bio-fibres
(Malkapuram et al., 2009). The most commonly used thermoplastics for structural applications are polypropylene, polyethylene, and poly vinyl chloride (PVC); while phenolic, epoxy and polyester resins are the most commonly used thermosetting matrices (Malkapuram et al., 2009). Most plastics possess low impact strength in their natural forms (American Chemistry Council, 2019); hence there is need for reinforcement which enhances the mechanical properties. Reinforced polymer composite has found its applications in variety of places such as the automobile industry like the car bumper, among others. Although, this bumper has been produced to possess good mechanical properties, but has tendency to break when subjected to little or no impact forces, which has become a problem to Engineers (Mazumbar, 2001). Meanwhile, studies revealed that the manufacturers were able to meet automotive requirements of cost, appearance and performance utilizing composites (Mazumbar, 2001). Currently, composite body panels have a successful track record in all categories from exotic sports cars to passenger cars to small, medium, and heavy truck applications. In 2000, the automotive industry used 318 million pounds of composites. Because the automotive market is very cost-sensitive, carbon fiber composites are not yet accepted due to their higher material costs. 
Automotive composites utilize glass fibers as main reinforcements (Mazumdar, 2001).

Epoxy resins are thermosetting polymers with good chemical resistance, high mechanical properties and thermal stability, high adhesive strength as well as high electrical insulation (Agarwal et al., 2017). For high performance applications in aerospace and marine structures, epoxy resins are used. This is as a result of its ease processing, hot and wet strength in conjunction with excellent mechanical properties in composites (Mukhopadhway, 2005). According to Mukhopadhway (2005), superior mechanical properties and better resistance to degradation made the performance of epoxy to be similar to that of polyester. Reinforcement could be either fiber reinforced, particle reinforced, flat flakes reinforced or filler reinforced. Fillers are added to a polymer formulation to reduce the costs and improve the properties. Fillers can either be solid, liquid or gas. They occupy space and replace the expensive resin with less expensive compounds without modifying other characteristics.

In this study, cow horn is being considered as the filler in an epoxy composite, being a material containing fibrous protein material called keratin (McKittrick et $a l ., 2012)$. It has been regarded as a viable reinforcing material. It is a tough, resilent, very ductile material that possesses highly resistant to impact with its reasonable amount of carbon present (Kumar \& Boopathy, 2014; McKittrick et al., 2012). This study therefore aims at testing cow horn as a suitable composite reinforcing material (filler) and imperative to produce composite with excellent mechanical properties which are also quite affordable as well as possess vast applications.

\section{MATERIALS AND METHODS}

The materials used in this study include cow horns; epoxy resin and catalyst which were respectively obtained at Sobi-Ilorin abattoir (Kwara State, Nigeria) and from a local vendor at Ojota, Lagos State, Nigeria. The cow horn was thoroughly washed and air dried to remove debris on it. Subsequently, the air-dried cow horn samples were oven dried using a conventional oven at $100^{\circ} \mathrm{C}$ for 126 hours to completely remove moisture in the horn.

Figure 1 shows the cow horn samples in the oven for drying. The dried cow horn samples were crushed using a SNE FOURE Hammer Mill and then transferred to a "Broyeur-clero" ball mill (Figure 2). The milling operation was carried out for 22 hours. The milled cow horn was then sieved manually, using
100 microns and 150 microns sieves, to segregate two different sizes of horn particles.
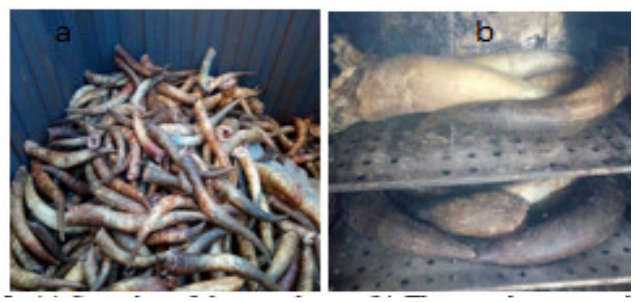

Fig 1: (a) Samples of the cow horns (b) The cow horn samples in the oven ready for drying

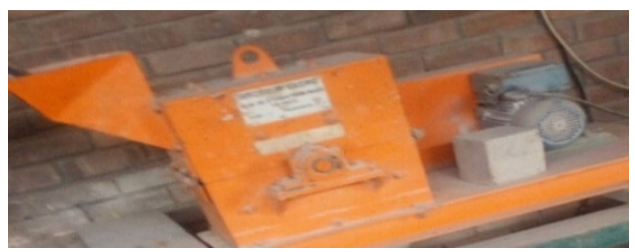

Fig 2: Broyeur-clero" hammer mill used for crushing

Production of Epoxy Composite: The epoxy and each of 100 and $150 \mu \mathrm{m}$ cow horn (were separately measured using an electronic measuring scale in different ratios as presented in Table 1 and kept separately in different containers (Figure 3a). In activating the resin, it was gradually mixed with the catalyst (hardener). A lot of care was taken at this stage, since rapid mixing might allow air bubbles to get trapped into the mixture. The weighted cow horn samples were then added to this mixture and mixed for about 5 minutes till homogeneity was attained. The Mixture of cow horn and resin is shown in Figure $3 b$.

The cow horn and epoxy were then poured into the wooden mould (Figure 4a) and allowed to cool. The moulds were left, after proper marking, for natural curing at room temperature for 72 hours (Figure 4b). To reduce the negative effects of polymerization shrinkage and increase hardness and wear resistance of the lightly cured resin composite samples (Figure $4 \mathrm{c}$ ), post curing (heat treatment) of the specimens was done in a conventional oven at varying curing temperatures of 60 and $80^{\circ} \mathrm{C}$.

This process was also to further harden, set the cast epoxy resin composites and to increase its mechanical properties. This process was in line with the practice of earlier researchers (Irawan et al., 2011; Khondker et al., 2005; Bello et al., 2015).

Table 1: Mixing ratios of specimen

\begin{tabular}{|c|c|c|c|c|c|c|c|c|c|}
\hline pec & & & & & & & & & \\
\hline Con & & 40 & 35 & 30 & 25 & 20 & 15 & 10 & \\
\hline & 100 & 60 & 65 & 70 & 75 & 80 & 82 & 90 & \\
\hline
\end{tabular}



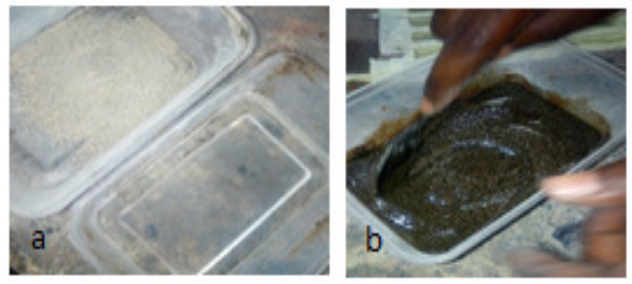

Fig 3: (a) Measured quantity of cow horn and epoxy, (b) Mixture of cow horn and resin

Determination of the Corn Horn Elemental Chemical Composition: The external cover of the horn (hoofs) were removed and soaked in water to make them free of blood and dirty materials. Subsequently, the cleaned horn was cut into smaller chips and rewashed in hot water and later sun-dried for 15 days. The elemental chemical composition of the corn horn sample was carried out using Shimadzu 720 XRF Analyzer (Maker: Shimadzu Cooperation, Japan).

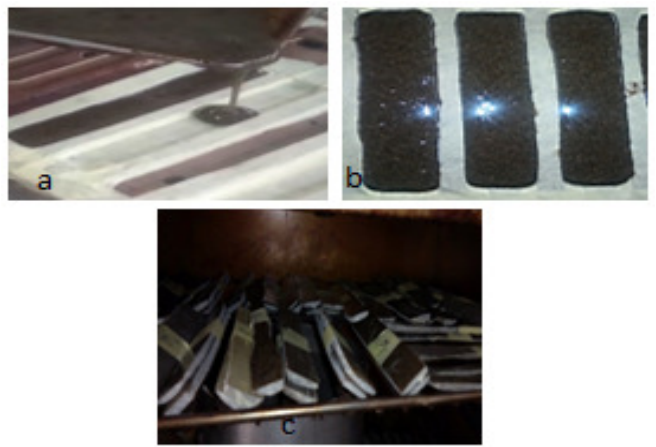

Fig 4: (a) Pouring of the cow horn mixture into the mould cavity, (b) Specimens at room temperature for curing, (c) Sets of specimens arranged in the oven for post curing

Characterization of the composite samples: The mechanical properties (such as tensile, flexural and impact properties) of the specimens were determined to characterize the composite produced, in line with the practices of Irawan et al., (2011); Khondker et al., (2005); Viviane et al. (2006); Kumar and Sankar (2019). The samples for tensile test were prepared and the test was conducted in accordance with the ASTM D638 / ASTM D3039 / D3039M - 17 standards.
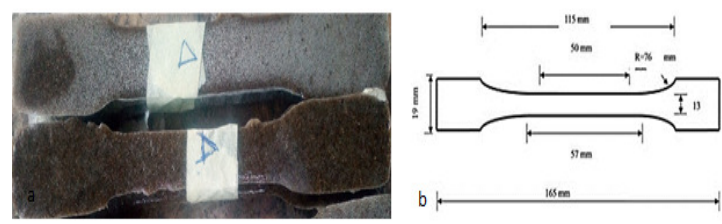

Fig 5: Tensile Samples

Figures 5 ( $a$ and $b$ ) shows the tensile test sample and its ASTM dimensions respectively. The tensile and flexural properties of the samples were determined at the National Centre for Agricultural Mechanization
Ilorin, Nigeria Universal Testing Machine Laboratory using Win Test Analysis on Testometric Materials Testing Machine; Type DBBMTCL-5000 Kg, Serial No. 17819 (Figure 6). The thickness of each of the samples was measured at three different positions along the length of the specimen and the average thickness was used for calibration. The test speed used was $5.0 \mathrm{~mm} / \mathrm{min}$ with the gauge length fixed at 57.00 $\mathrm{mm}$. Eight samples were tested for each test type.

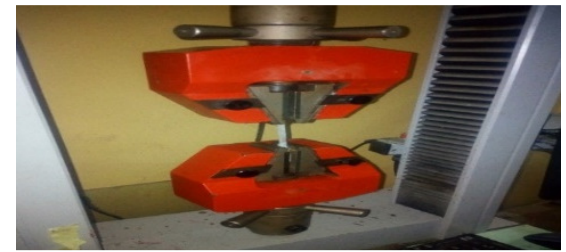

Fig 6: Testometric machine with the specimen wedged between its grips

The flexural samples were prepared and the test was carried using ASTM D790-03 as a guide. The flexural test was evaluated using three-point bending flexural test, as recommended in ASTM D790-03 (Pham et al. 2014; Irawan et al., 2011; Kumar and Sankar, 2019). Figure 7 ( $a$ and $b$ ) shows the pictorial flexural test sample dimensions as stipulated in ASTM standards and the impact machined used for the test respectively.

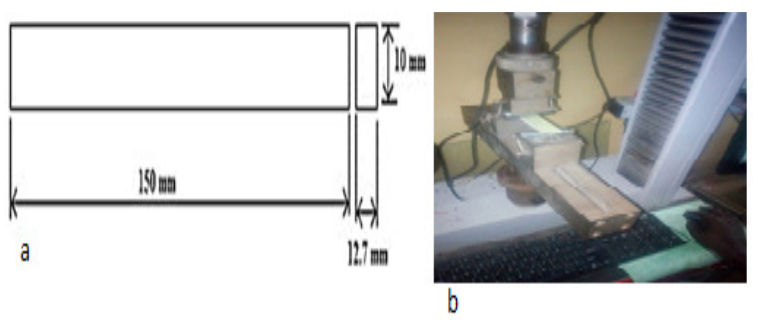

Fig 7: (a) Pictorial representation of specimen for flexural test with dimensions; (b) Testometric machine with a flexural specimen

The samples for the impact test were prepared as presented in Figure 8 and the test was carried out in accordance with the guidelines in ASTM D256-04 standard at Department of Mechanical Engineering, University of Ilorin, Nigeria.
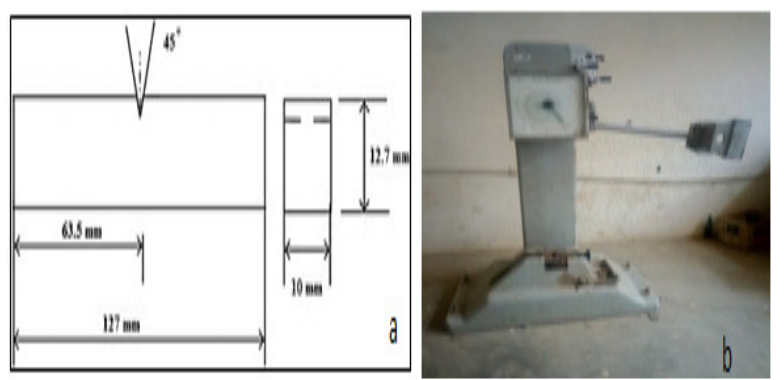

Fig 8: (a) Pictorial representation of specimen for impact test; (b) The Impact testing machine used 


\section{RESULTS AND DISCUSSION}

The results of the elemental chemical composition of the corn horn sample are presented in Table 2. The major component was Sulphur (78.23\%), while calcium $(8.10 \%)$ and Molybdenum (5.80 \%) constitute another significant element in the material. The values of the elemental composition of the corn horn were within the range values earlier discovered by Abdullahi and Salihi (2007).

\begin{tabular}{|c|c|c|}
\hline $\mathbf{S} / \mathbf{N}$ & Elements & Percentage \\
\hline 1 & Sulphur & 78.23 \\
\hline 2 & Calcium & 8.10 \\
\hline 3 & Potassium & 0.80 \\
\hline 4 & Copper & 0.21 \\
\hline 5 & Zinc & 2.00 \\
\hline 6 & Molybdenum & 5.80 \\
\hline 7 & Aluminum & 0.30 \\
\hline 8 & Silicon & 0.13 \\
\hline 9 & Indium & 0.5 \\
\hline 10 & Rhenium & 2.3 \\
\hline 11 & Selenium & 1.0 \\
\hline
\end{tabular}

The various tensile strengths exhibited by the composite (cow horn/epoxy) samples were determined and studied considering various sizes of the composites $(100 \mu \mathrm{m}$ and $150 \mu \mathrm{m})$ at varying curing temperatures. The results are presented in Figures 9 and 10 .

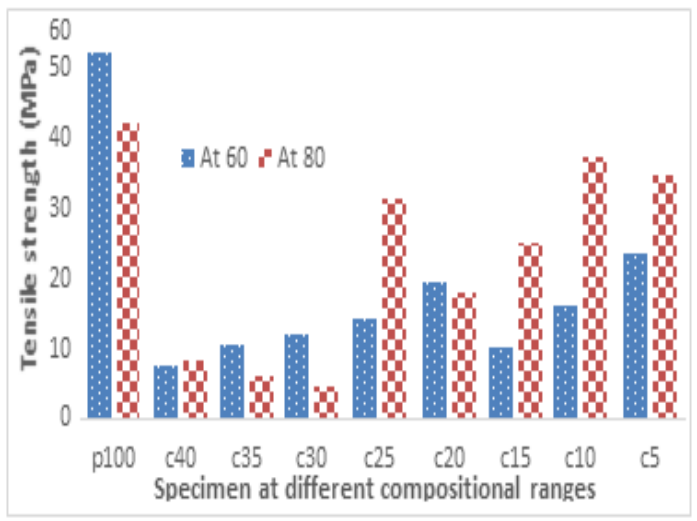

Fig 9: Tensile strength of specimens at $100 \mu \mathrm{m}$ with different curing temperature variation

Figure 9 shows the tensile strength variation of the various specimens at $100 \mu \mathrm{m}$. The results indicate that specimen p100 with curing temperature of $60^{\circ} \mathrm{C}$ exhibited the highest tensile strength of 52.29 Mpa, while that of $80^{\circ} \mathrm{C}$ curing temperature has strength value of $42.18 \mathrm{Mpa}$. This implies that curing temperature has significant effect on the tensile strength of the p100 sample. Generally, the values of the specimens' strengths were between 6.25 MPa and $52.29 \mathrm{MPa}$. The results revealed a drastic reduction in the strength values of the p100 with addition of cow horn. This might be as a result of poor compatibility between the matrix and cow horn particle. According to (Kumar et al. (2017), effective load transfer between the matrix and the particles serves as the base for the tensile strength of a particle-reinforced polymer matrix composite. Addition of cow horn as filler decreased the tensile strength of the composite in no particular order. Considering specimen c40, the tensile strength of the composite was found to be $8.29 \mathrm{MPa}$ with curing temperature of $80^{\circ} \mathrm{C}$, but the specimen with curing temperature of $60^{\circ} \mathrm{C}$ recorded a low tensile strength value of 7.71 $\mathrm{MPa}$. In the case of specimen c35 with curing temperature of $80^{\circ} \mathrm{C}$, the tensile strength increased to $10.46 \mathrm{MPa}$, but the specimen with curing temperature of $60^{\circ} \mathrm{C}$ has a lower value of 6.25 $\mathrm{MPa}$. The specimen $\mathrm{C} 30$ with curing temperature of $80^{\circ} \mathrm{C}$ and one with curing temperature of $60^{\circ} \mathrm{C}$ respectively recorded tensile strength value of 4.71 $\mathrm{MPa}$ and 12.08 MPa. For specimen c25, the result shows a significant difference in the tensile strength with a value of $31.33 \mathrm{MPa}$ (with curing temperature of $80^{\circ} \mathrm{C}$ ) and $14.13 \mathrm{Mpa}$ (with curing temperature of $60^{\circ} \mathrm{C}$ ). Specimen c20 has a tensile strength of 18.08 $\mathrm{MPa}$ at $80^{\circ} \mathrm{C}$ and $19.42 \mathrm{MPa}$ at $60^{\circ} \mathrm{C}$. Specimen c15 exhibited a tensile strength of $25.13 \mathrm{MPa}$ and 10.04 $\mathrm{MPa}$ with curing temperature of $80^{\circ} \mathrm{C}$ and curing temperature of $60^{\circ} \mathrm{C}$ respectively. Specimen c10 shows an appreciable tensile strength value of 37.58 $\mathrm{MPa}$ (with curing temperature of $80^{\circ} \mathrm{C}$ ). Specimen c5 has tensile strength value of $34.83 \mathrm{MPa}$ and $23.46 \mathrm{MPa}$ with curing temperature of $80^{\circ} \mathrm{C}$ and with curing temperature of $60^{\circ} \mathrm{C}$ respectively. The results analysis apparently revealed reduction in the strength of the composite. According to Duraisamy et al. (2017), horse particles in the composite create weakness in the adhesive force between the resin and the filler (horse particle) because horse particle acts as stress concentration points. Thus, the strength of the virgin epoxy composites decreases.

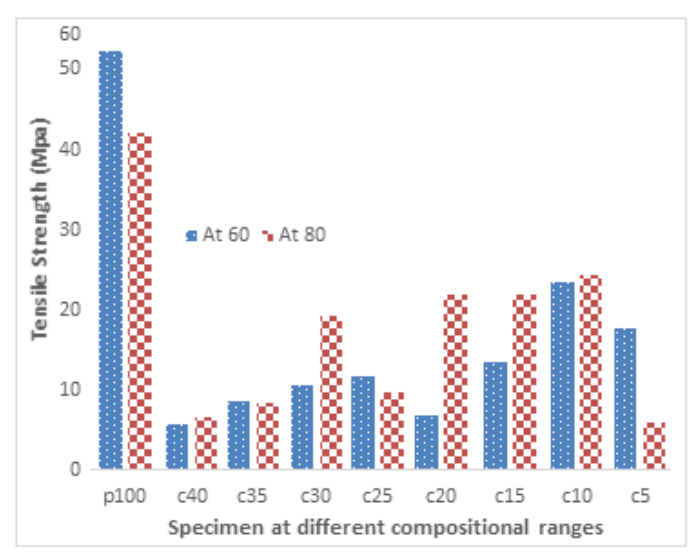

Fig 10: Tensile strength of specimens at $150 \mu \mathrm{m}$ with different curing temperature variation 
Figure 10 shows the tensile strength variation of the various specimens at $150 \mu \mathrm{m}$. The results indicate that the specimen p100 with curing temperature of $60^{\circ} \mathrm{C}$ has the highest tensile strength value of 52.29 $\mathrm{MPa}$, while that of $80^{\circ} \mathrm{C}$ curing temperature has strength value of $42.18 \mathrm{MPa}$. This reflects significant effect of curing temperature on the tensile strength of the p100 sample. Generally, the values of the specimens' tensile strengths were between 7.71 $\mathrm{MPa}$ and 23.46 $\mathrm{MPa}$ for samples with curing temperature of $60^{\circ} \mathrm{C}$ and between 4.71and $37.58 \mathrm{MPa}$ for samples with curing temperature of $80^{\circ} \mathrm{C}$ (with particle size of $100 \mu \mathrm{m}$ ). Meanwhile, samples with particle size $150 \mu \mathrm{m}$ have tensile strengths between 5.77 $\mathrm{MPa}$ and $23.50 \mathrm{MPa}$ (with curing temperature of $60^{\circ} \mathrm{C}$ ), and 6.042 and 24.38 MPa (for samples with curing temperature of $\left.80^{\circ} \mathrm{C}\right)$. The results revealed a drastic reduction in the strength values of the p100 (52.29 MPa and 42.2 MPa with curing temperature of $60^{\circ} \mathrm{C}$ and $80^{\circ} \mathrm{C}$ respectively) with addition of cow horn. Poor compatibility between the particles and cow horn particle-reinforced polymer matrix composite is likely to be a factor (Kumar et al., 2017). Addition of cow horn as filler decreased the tensile strength of the composite in no particular order. At specimen c40, the tensile strength of the composite with curing temperature of $80^{\circ} \mathrm{C}$ was found to be $6.71 \mathrm{MPa}$, while same sample with $60^{\circ} \mathrm{C}$ curing temperature has a low tensile strength value of 5.79 MPa. For sample c35, the sample with $80^{\circ} \mathrm{C}$ curing temperature and that with $60^{\circ} \mathrm{C}$ curing temperature exhibited strength value of 8.67 MPa and 8.33 MPa respectively. Sample c30 has tensile strength value of $19.21 \mathrm{MPa}$ and $10.71 \mathrm{MPa}$ for at $80^{\circ} \mathrm{C}$ at $60^{\circ} \mathrm{C}$. At c25, the result shows a significant difference in the tensile strength with a value of 9.63 $\mathrm{MPa}$ (with curing temperature of $80^{\circ} \mathrm{C}$ ) and $11.63 \mathrm{MPa}$ (with curing temperature of $60^{\circ} \mathrm{C}$ ). Specimen c 20 have tensile strength of $21.88 \mathrm{MPa}$ (with curing temperature of $80^{\circ} \mathrm{C}$ ) and $6.88 \mathrm{MPa}$ (with curing temperature of $60^{\circ} \mathrm{C}$ ). For specimen $\mathrm{c} 15$, the tensile strength exhibited was $22.00 \mathrm{MPa}$ for sample with curing temperature of $80^{\circ} \mathrm{C}$ and a lower value of $13.58 \mathrm{MPa}$ for sample with curing temperature $60^{\circ} \mathrm{C}$. Specimen c10 shows an appreciable tensile strength value of $24.38 \mathrm{MPa}$ with curing temperature of $80^{\circ} \mathrm{C}$. Specimen c5 for sample with curing temperature $80^{\circ} \mathrm{C}$ and sample with curing temperature of $60^{\circ} \mathrm{C}$ has tensile strength value of 6.04 $\mathrm{MPa}$ and $17.79 \mathrm{MPa}$ respectively. From these results (Figures $9 \& 10$ ), it is obvious that the specimens of $100 \mu \mathrm{m}$ particle size had better tensile strength values than specimens of $150 \mu \mathrm{m}$ particle size. According to Fu et al. (2008) particle size, good bonding strength between fibre particles and resins, and particle loading are parts of factors that affect the strength.

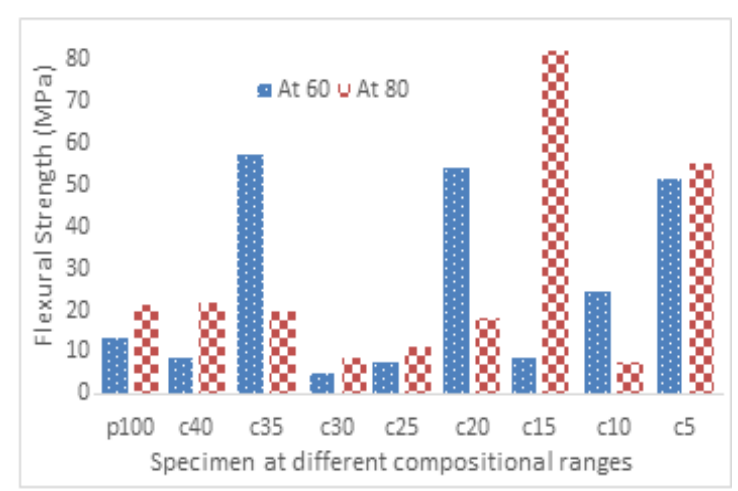

Fig 11: Flexural strength of specimens at $100 \mu \mathrm{m}$ with different curing temperature variation

Figure 11 shows the flexural strength variation of the various specimens at $100 \mu \mathrm{m}$. The results indicate that the flexural strength of specimen p100 with curing temperature of $60^{\circ} \mathrm{C}$ was $13.23 \mathrm{MPa}$, while that of $80^{\circ} \mathrm{C}$ curing temperature's strength value was 21.58 $\mathrm{MPa}$. This implies that curing temperature also has significant effect on the flexural strength of the p100 sample. Generally, the recorded values of the specimens' flexural strengths for samples of particle size of $100 \mu \mathrm{m}$ were between 4.97 $\mathrm{MPa}$ and 57.11 MPa (samples with curing temperature of $60^{\circ} \mathrm{C}$ ) and between 7.44 and 82.36 (samples with curing temperature of $80^{\circ} \mathrm{C}$ ). The results also revealed an increase in the flexural strength values of the specimen p100 (13.23 / $60^{\circ} \mathrm{C}$ and $\left.21.59 / 80^{\circ} \mathrm{C}\right)$ with addition of cow horn. Addition of cow horn as filler in the composite increased the flexural strength of the composite in no particular order. For specimen c40, the flexural strength of the composite sample with curing temperature of $80^{\circ} \mathrm{C}$ was found to be 21.90 $\mathrm{MPa}$, while sample with curing temperature of $60^{\circ} \mathrm{C}$ recorded a low tensile strength value of $8.62 \mathrm{MPa}$. At specimen c35, the flexural strength was $57.11 \mathrm{MPa}$ for sample with curing temperature of $60^{\circ} \mathrm{C}$, but sample with $80^{\circ} \mathrm{C}$ curing temperature exhibited a lower value of $19.94 \mathrm{MPa}$. Specimen c30 recorded flexural strength value of $8.54 \mathrm{MPa}$ and $4.92 \mathrm{MPa}$ for sample with curing temperature of $80^{\circ} \mathrm{C}$ and $60^{\circ} \mathrm{C}$ respectively. For specimen $\mathrm{c} 25$, the result shows a significant difference in the flexural strength with a value of $11.31 \mathrm{MPa}$ at $80^{\circ} \mathrm{C}$ curing temperature and $7.58 \mathrm{Mpa}$ at $60^{\circ} \mathrm{C}$ curing temperature. Specimen c20 has a flexural strength of $54.16 \mathrm{Mpa}$ with curing temperature $60^{\circ} \mathrm{C}$ and $18.18 \mathrm{MPa}$ with curing temperature $80^{\circ} \mathrm{C}$. For specimen $\mathrm{c} 15$, the flexural strength was $82.36 \mathrm{MPa}$ (with $80^{\circ} \mathrm{C}$ curing temperature) but with a lower value of $8.54 \mathrm{MPa}$ for sample with $60^{\circ} \mathrm{C}$ curing temperature. Specimen c10 has a flexural strength value of 24.31 MPa with curing temperature of $60^{\circ} \mathrm{C}$. Specimen c5 in its own case has flexural strength value of $55.27 \mathrm{MPa}$ with curing 
temperature $80^{\circ} \mathrm{C}$ and $51.73 \mathrm{MPa}$ with $60^{\circ} \mathrm{C}$ curing temperature. The analysis of the results revealed that the post curing temperature has noticeable effect on the flexural strength of the composite. The analysis of flexural strength results shows that the specimens with smaller particle sizes of $100 \mu \mathrm{m}$ exhibited higher flexural strength value than specimen of higher particle sizes of $150 \mu \mathrm{m}$, though at higher curing temperature. This result is in line with the findings of Duraisamy et al. (2017) that smallest horn powder size in composite gives better strength as a result of the fact that smaller particles have better dispersion and high surface area with the matrix. Figure 12 shows the flexural strength variation of the various specimens at $150 \mu \mathrm{m}$. Generally, the specimens' flexural strengths were between 5.31 MPa and 30.74 MPa (samples with curing temperature of $60^{\circ} \mathrm{C}$ ) and between 3.97 and 41.34 $\mathrm{MPa}$ (samples with curing temperature of $80^{\circ} \mathrm{C}$ ). The results indicate that the flexural strength of specimen p100 with curing temperature of $60^{\circ} \mathrm{C}$ has a low flexural value of $13.24 \mathrm{MPa}$ as compared to when its curing temperature was $80^{\circ} \mathrm{C}(21.58 \mathrm{MPa})$. The general values of the specimens' flexural strengths were between 4.97 $\mathrm{MPa}$ and 55.27 $\mathrm{MPa}$. The results revealed an increase in the flexural strength values of specimen p100 with addition of cow horn. Also, addition of cow horn of particle size $150 \mu \mathrm{m}$ as filler in the composite increased the flexural strength of the composite in no particular order.

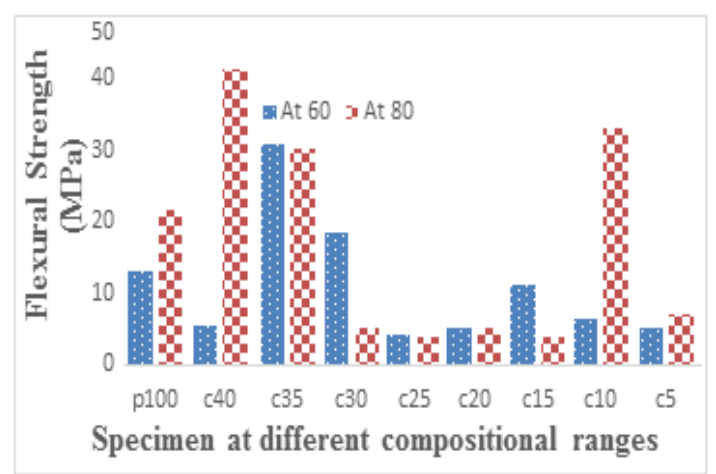

Fig 12: Flexural strength of specimens at $150 \mu \mathrm{m}$ with different curing temperature variation

At specimen c40, the flexure strength of the composite was found to be $41.34 \mathrm{MPa}$ for sample with curing temperature of $80^{\circ} \mathrm{C}$, but recorded a low flexural strength value for sample with curing temperature of $60^{\circ} \mathrm{C}(5.398 \mathrm{MPa})$. Considering specimen $\mathrm{c} 35$, the flexural strength of sample with curing temperature of $80^{\circ} \mathrm{C}$ and that sample with curing temperature of $60^{\circ} \mathrm{C}$ were little or no difference in values of $30.21 \mathrm{MPa}$ and $30.74 \mathrm{Mpa}$ respectively. This might be as a result of a good compatibility between the horn particles and the epoxy at that composition (Kumar et al. 2017). For specimen c30, there was a drastic drop in the flexural strength to $5.06 \mathrm{MPa}$ for sample with curing temperature of $80^{\circ} \mathrm{C}$ and a value of $18.47 \mathrm{MPa}$ for sample with curing temperature of $60^{\circ} \mathrm{C}$. Low flexural strength values were recorded for specimens' c25 and c20 in an ascending order. Specimen c10 also exhibited a high flexural strength for sample with curing temperature of $80^{\circ} \mathrm{C}(33.05 \mathrm{MPa})$. At specimen $\mathrm{c5}$, the flexural strength value was $7.09 \mathrm{MPa}$ for sample with curing temperature of $80^{\circ} \mathrm{C}$ and $5.31 \mathrm{MPa}$ for sample with curing temperature of $60^{\circ} \mathrm{C}$. The results revealed that the post curing temperature has a noticeable effect on the flexural strength of the composite. From the obtained results, the highest flexural strength was obtainable with sample c5, 100 $\mu \mathrm{m}$ particle sizes with curing temperature of $80^{\circ} \mathrm{C}$. Figure 12 shows the flexural strength variation of the various specimens at $150 \mu \mathrm{m}$. Generally, the specimens' flexural strengths were between 5.31 MPa and $30.74 \mathrm{MPa}$ (samples with curing temperature of $60^{\circ} \mathrm{C}$ ) and between 3.97 and 41.34 MPa (samples with curing temperature of $80^{\circ} \mathrm{C}$ ). The results indicate that the flexural strength of specimen p100 with curing temperature of $60^{\circ} \mathrm{C}$ has a low flexural value of 13.24 $\mathrm{MPa}$ as compared to when its curing temperature was $80^{\circ} \mathrm{C}(21.58 \mathrm{MPa})$. The general values of the specimens' flexural strengths were between 4.97 MPa and 55.27 $\mathrm{MPa}$. The results revealed an increase in the flexural strength values of specimen p100 with addition of cow horn. Also, addition of cow horn of particle size $150 \mu \mathrm{m}$ as filler in the composite increased the flexural strength of the composite in no particular order.

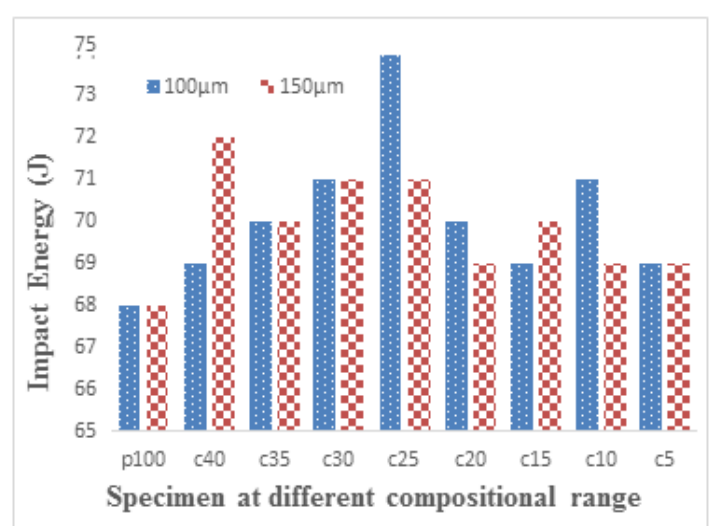

Fig 13: Impact strength of specimens with different size particles variation

In Figure 13, the impact energy variations for the various specimens at $60^{\circ} \mathrm{C}$ are presented. In general, the specimens' impact values ranged between 69 and $74 \mathrm{~J}$ for samples of $100 \mu \mathrm{m}$ particle size, and between 69 and $72 \mathrm{~J}$ for samples of $100 \mu \mathrm{m}$ particle size. The results indicate that the impact energy of p100 was 68 
J. Specimen c40 has impact energy of $72 \mathrm{~J}$ at $100 \mu \mathrm{m}$ particle size and impact energy of $68 \mathrm{~J}$ at particle size of $150 \mu \mathrm{m}$. Specimen c30 has the same impact value of $71 \mathrm{~J}$ at both size variations. Specimen c 25 recorded the highest the impact energy of $74 \mathrm{~J}$ at $100 \mu \mathrm{m}$. Specimen c20 has an impact energy value of $70 \mathrm{~J}$ and $69 \mathrm{~J}$ at particle sizes of $100 \mu \mathrm{m}$ and $150 \mu \mathrm{m}$ respectively. Specimen c15 also recorded an impact value of $69 \mathrm{~J}$ and $70 \mathrm{~J}$ at $100 \mu \mathrm{m}$ and $150 \mu \mathrm{m}$ respectively. Specimen c10 has impact energy of $71 \mathrm{~J}$ at $100 \mu \mathrm{m}$ particle size, while at $150 \mu \mathrm{m}$ particle size impact energy of $69 \mathrm{~J}$ was recorded. Specimen c5 also has the same impact energy at both size variations (100 $\mu \mathrm{m}$ and $150 \mu \mathrm{m}$ particle sizes) with a value of $69 \mathrm{~J}$. From the results obtained, specimen c25 has the highest impact energy (74 J) with particle size of 100 $\mu \mathrm{m}$. Though, $\mathrm{c} 40$ recorded very close impact energy value of $72 \mathrm{~J}$ with particle size of $150 \mu \mathrm{m}$. The increase in the impact strength of the new composite is an indication of good bonding strength of the specimens.

Conclusions: At higher curing temperature, better flexural, impact and tensile properties were achieved in the polymers with the incorporation of the cow horn as filler. Also, the composite materials with particle size of $100 \mu \mathrm{m}$ with curing temperature of $80^{\circ} \mathrm{C}$ exhibited higher tensile and impact properties. Therefore, the cow horn was found to be a good potential filler in the composite if prepared using higher curing temperature as exhibited through its mechanical properties. A composite prepared at $150 \mu \mathrm{m}$ mixture is highly recommended for an impact application of the composited especially for material engineering to be subjected to impact application. Further research works on the use of cow horn as filler in epoxy composite and also the effect of alkali treatment on the compatibility of the cow horn particles and epoxy are recommended

\section{REFERENCES}

Abdullahi, U; Salihi, A (2007). Characterization and Potential Application of Kano Cattle Horn. J. Eng. and Technol., 32-40

Agarwal, BD; Broutman, LJ; Chandrashekhara, K (2017). Analysis and performance of fiber composites: John Wiley \& Sons, United States, pp $1-576$

Arda, S (2018). Fiber Reinforced Composites. Efunda Inc. Available online: https://www.efunda.com, Accessed on November 25, 2018

American Chemistry Council (2019). How Plastics are Made: The Basics of Plastic Manufacturing. Available online:
https://plastics.americanchemistry.com/HowPlastics-Are-Made/, Accessed on February 26, 2019

ASTM D790-03 (2003). Test methods for Flexural Properties of Unreinforced and Reinforced Plastics and Electrical Insulating Materials. ASTM International, West Conshohocken (PA)

ASTM D256-04 (2010). Standard Test Methods for Determining the Izod Pendulum Impact Resistance of Plastics, ASTM International, West Conshohocken (PA)

ASTM D638-10 (2010). Standard Test Methods for Tensile Properties of Plastics. ASTM International, West Conshohocken, PA

ASTM D3039 / D3039M - 17: Standard Test Method for Tensile Properties of Polymer Matrix Composite Materials, ASTM International, West Conshohocken (PA)

Bello, SA; Agunsoye, JO; Hassan, SB; Kana, MGZ, Raheem, IA. (2015). Epoxy Resin Based Composites, Mechanical and Tribological Properties: A Review, Trib. Ind., 1-29

Duraisamy, K; Sadayan, RB; Dharmalingam, S; Govindarajan, B (2017). Investigation of Mechanical Properties of Horn Powdered-Filled Epoxy Composites, J. of Mech. Eng., 63(2), 136147

Fang, L, Shiqiang, D and Jianing, Z (2017). Mechanical Properties of Epoxy and its Carbon Fiber Composites Modified by Nanoparticles, Hindawi J. of Nanomaterials, 1- 9.

Fu, SY; Feng, XQ; Lauke, B; Mai, YW (2008). Effects of Particle Size, Particle/Matrix Interface Adhesion and Particle Loading on Mechanical Properties of Particulate-Polymer Composites: Part B: Engineering, 30 (6), 933-961

Irawan, AP; Soemardi, TP; Widjajalaksmi, K; Reksoprodjo, AHS (2011). Tensile and Flexural Strength of Ramie Fiber Reinforced Epoxy Composites for Socket Prosthesis Application. Intl J Mech. Matls. Eng. (IJMME), 6(1): 46-50

John, V (1992). Introduction to Engineering Materials: Macmillan Press Ltd., London, pp 1-503

AMBALI, IO; SHUAIB-BABATA, YL; ALASI, TO; AREMU, IN; IBRAHIM, HK; ELAKHAME, ZU; 
Jones, RM (2014). Mechanics of Composite Materials. CRC Press, Florida, pp 1-538

Khondker, OA; Ishiaku, US; Nakai, A; Hamada, H (2005). Tensile, Flexural and Impact Properties of Jute Fibre-Based Thermosetting Composites, Plastics, Rubber and Composites, 34(10), 450-462

Kumar, D; Boopathy, SR (2014). Mechanical and Thermal Properties of Horn Fibre Reinforced Polypropylene Composites, Procedia Engineering, 97, 648-659

Kumar, D; Rajendra, BS; Dharmalingam, S; Govindarajan, B (2017). Investigation of Mechanical Properties of Horn-Filled Epoxy Composite. J of Mech Eng., 138-147

Kumar, GKK; Sankar, CB (2019). Mechanical Behaviour of Silicon Carbide (Sic) / Fly Ash Particles Reinforced Aluminium-7075 Based Metal Matrix Composite Fabricated by Stir Casting Method. IJSART, 5(2): 2395-1052

Malkapuram, R; Kumar, V; Negi, YS (2009). Recent Development in Natural Fiber Reinforced Polypropylene Composites. J. Reinforced Plastics Composites, 28(10), 1169-1189

Mazumdar, S (2001). Composites Manufacturing: Materials, Product, and Process Engineering: CRC Press, Florida
McKittrick, J; Chen, PY; Bodde, S; Yang, W; Novitskaya, E; Meyers, M (2012). The Structure, Functions, and Mechanical Properties of keratin. Jom, 64(4), 449-468

Mukhopadhyay, M (2005). Mechanics of Composite Materials and Structures, Universities Press, Universities Press Pvt. Ltd., India, pp xiv - 371

Pham, H L; Do, B T; Pham, TS; Le, DG (2014). Effect of Different Types of Liquid Natural Rubbers on the Modification of Dgeba-based Epoxy Resin. Tap chf Khoa hoc vA Cong nghe, 52 (6): 743-75

Saheb, DN; Jog, JP (1999). Natural Fiber Polymer Composites: A Review. Adv. Polymer Tech., 18(4), 351-363.

Shao-Yun F; Xi-Qiao F; Bernd L; Yiu-Wing MXQF; Bernd Lauke,Y (2008). Effects of Particle Size, Particle/Matrix Interface Adhension and Particle Loading on Mechanical Properties of ParticulatePolymer Composites. Composites, Part B39, 933967

Viviane, G; Fabio L B; Bluma, G S (2006). Composite materials based on modified epoxy resin and carbon fiber, J. Braz. Chem. Soc. 17(6):1117 1123 